\title{
Beta Particle
}

National Cancer Institute

\section{Source}

National Cancer Institute. Beta Particle. NCI Thesaurus. Code C94864.

An electron or positron. 